\title{
One year of Raman lidar observations of free-tropospheric aerosol layers over South Africa
}

\author{
E. Giannakaki ${ }^{1}$, A. Pfüller ${ }^{1}$, K. Korhonen ${ }^{1,2}$, T. Mielonen ${ }^{1}$, L. Laakso ${ }^{3,4}$, V. Vakkari ${ }^{3}$, H. Baars ${ }^{5}$, R. Engelmann ${ }^{5}$, \\ J. P. Beukes ${ }^{4}$, P. G. Van Zyl ${ }^{4}$, M. Josipovic ${ }^{4}$, P. Tiitta ${ }^{4,6}$, K. Chiloane ${ }^{7}$, S. Piketh ${ }^{4}$, H. Lihavainen ${ }^{3}$, K. E. J. Lehtinen ${ }^{1,2}$, \\ and M. Komppula ${ }^{1}$ \\ ${ }^{1}$ Finnish Meteorological Institute, P.O. Box 1627, 70211, Kuopio, Finland \\ ${ }^{2}$ Department of Applied Physics, University of Eastern Finland, P.O. Box 1627, 70211 Kuopio, Finland \\ ${ }^{3}$ Finnish Meteorological Institute, P.O. Box 503, 00101, Helsinki, Finland \\ ${ }^{4}$ Unit for Environmental Sciences and Management, North-West University, Potchefstroom, South Africa \\ ${ }^{5}$ Leibniz Institute for Tropospheric Research, Permoserstrasse 15, 04318, Leipzig, Germany \\ ${ }^{6}$ Department of Environmental Sciences, University of Eastern Finland, P.O. Box 1627, 70211 Kuopio, Finland \\ ${ }^{7}$ Eskom Holdings SOC Ltd, Sustainability Division; Research, Testing and Development, Johannesburg, South Africa
}

Correspondence to: Elina Giannakaki (eleni.giannakaki@fmi.fi)

Received: 26 November 2014 - Published in Atmos. Chem. Phys. Discuss.: 16 January 2015

Revised: 21 April 2015 - Accepted: 22 April 2015 - Published: 19 May 2015

\begin{abstract}
Raman lidar data obtained over a 1 year period has been analysed in relation to aerosol layers in the free troposphere over the Highveld in South Africa. In total, 375 layers were observed above the boundary layer during the period 30 January 2010 to 31 January 2011. The seasonal behaviour of aerosol layer geometrical characteristics, as well as intensive and extensive optical properties were studied. The highest centre heights of freetropospheric layers were observed during the South African spring ( $2520 \pm 970 \mathrm{~m}$ a.g.l., also elsewhere). The geometrical layer depth was found to be maximum during spring, while it did not show any significant difference for the rest of the seasons. The variability of the analysed intensive and extensive optical properties was high during all seasons. Layers were observed at a mean centre height of $2100 \pm 1000 \mathrm{~m}$ with an average lidar ratio of $67 \pm 25 \mathrm{sr}$ (mean value with 1 standard deviation) at $355 \mathrm{~nm}$ and a mean extinctionrelated Ångström exponent of $1.9 \pm 0.8$ between 355 and $532 \mathrm{~nm}$ during the period under study. Except for the intensive biomass burning period from August to October, the lidar ratios and Ångström exponents are within the range of previous observations for urban/industrial aerosols. During Southern Hemispheric spring, the biomass burning activity is clearly reflected in the optical properties of the observed free-tropospheric layers. Specifically, lidar ratios at $355 \mathrm{~nm}$
\end{abstract}

were $89 \pm 21,57 \pm 20,59 \pm 22$ and $65 \pm 23$ sr during spring (September-November), summer (December-February), autumn (March-May) and winter (June-August), respectively. The extinction-related Ångström exponents between 355 and $532 \mathrm{~nm}$ measured during spring, summer, autumn and winter were $1.8 \pm 0.6,2.4 \pm 0.9,1.8 \pm 0.9$ and $1.8 \pm 0.6$, respectively. The mean columnar aerosol optical depth (AOD) obtained from lidar measurements was found to be $0.46 \pm 0.35$ at $355 \mathrm{~nm}$ and $0.25 \pm 0.2$ at $532 \mathrm{~nm}$. The contribution of freetropospheric aerosols on the AOD had a wide range of values with a mean contribution of $46 \%$.

\section{Introduction}

Atmospheric aerosols of natural and anthropogenic origin contribute substantially to global climate variability (IPCC, 2013). A detailed understanding of the regional geometrical characteristics and optical properties of aerosols, as well as their temporal and spatial distribution is required before we can accurately evaluate aerosol effects in the climate system (Hsu et al., 2000). However, high-quality aerosol measurements in the Southern Hemisphere are rather limited. South Africa is located at the southernmost tip of the African continent, extending from 22 to $34^{\circ} \mathrm{S}$ latitude and from 16 to 
$32^{\circ} \mathrm{E}$ longitude. Previous studies have indicated that South Africa is one of the most affected countries in the world with regard to aerosol load, due to various natural and anthropogenic activities (Piketh et al., 2000, 2002; Formenti et al., 2002, 2003; Campbell et al., 2003; Eck et al., 2003; Freiman and Piketh, 2003; Ichoku et al., 2003; Ross et al., 2003; Winkler et al., 2008; Queface et al., 2011; Tesfaye et al., 2011; Venter et al., 2012; Tiitta et al., 2014).

According to Giglio et al. (2010), $70 \%$ of the total area burned worldwide annually occurs in Africa. In order to assess the influence of wildfire aerosols on the climate system, it is important to know their altitude distribution. If wildfire aerosols are for example involved in cloud activation processes, it can alter cloud development through indirect and semi-direct aerosol effects (Ramanathan et al., 2001; Andreae et al., 2004; Koren et al., 2004, 2008; Rosenfeld et al., 2008). In addition, vertical transport can change the residence time and horizontal transport patterns of the absorbing aerosols. Vakkari et al. (2014) also recently showed that in biomass burning plumes in South Africa secondary aerosol formation increases significantly the aerosol mass and number concentrations during plume transport.

The Southern Hemisphere is relatively devoid of major dust activity (Prospero et al., 2002). In southern Africa one source of mineral dust is located in Botswana in the region centred at $21^{\circ} \mathrm{S}, 26^{\circ} \mathrm{E}$ with highly variable activity from year to year, while a second small but persistent source is centred at $16^{\circ} \mathrm{E}, 18^{\circ} \mathrm{S}$ over the Etosha Pan, an extremely flat salt pan in northern Namibia (Prospero et al., 2002; Bryant et al., 2007). Robles-Gonzalez and Leeuw (2008) have measured AODs of up to 0.75 at $555 \mathrm{~nm}$ over Namibian and Kalahari deserts during SAFARI-2000.

Long-term studies of atmospheric aerosols over the continental Southern Hemisphere are limited. In general, previous studies pointed out the importance of regional circulation and seasonal pollutant variation. In these long-term investigations the optical properties of aerosols have been studied by means of sun photometers (e.g. Queface et al., 2011), in situ data (e.g. Laakso et al., 2012) and satellite observations (e.g. Tesfaye et al., 2011). Sun photometers provide column optical properties from which microphysical information can be deduced. Although in situ surface observations provide detailed optical, chemical and microphysical characterization of particles, they are often point measurements. Optical properties of boundary layer aerosols that originate from local sources and regionally transported aerosols are usually different from free-tropospheric aerosols that generally originate from long-range transport.

Considering the above mentioned, there is a clear need for vertically resolved observations with advanced multiwavelength lidars. Lidar systems provide vertical profiles of atmospheric aerosols with a high temporal and spatial resolution. They are powerful tools for the geometrical characterization of free-tropospheric aerosols (e.g. Mattis et al., 2008) and for the analysis of aerosol optical properties (e.g.
Müller et al., 2007), which are the key factors in determining the impact of aerosols on solar radiation (Wagner et al., 2001). The optical characterization of aerosols is made possible with the independent detection of particle extinction and backscattering properties by the use of the Ramanlidar technique (Ansmann et al., 1992). Modern lidars are able to measure aerosol extinction coefficient profiles at two wavelengths and therefore determine the extinction-related Ångström exponent (Ångström, 1964), which contains information on particle size. Numerous studies (e.g. Ansmann et al., 2002; Müller et al., 2007; Groß et al., 2013; Mona et al., 2006) have demonstrated that the lidar ratio (i.e. extinctionto-backscatter ratio) is a valuable parameter for aerosol characterization since it depends on the particles' microphysical and chemical properties and therefore varies significantly for different aerosol types. Based on 10 years of lidar observations around the globe, intensive optical properties of several aerosol types were presented by Müller et al. (2007). However, long-term lidar studies often reveal high variability in the optical properties measured (Balis et al., 2004; Papayannis et al., 2008; Amiridis et al., 2009; Giannakaki et al., 2010; Hänel et al., 2012; Komppula et al., 2012; Baars et al., 2012) due to the high temporal and spatial variability of the aerosol occurrences.

The measurements presented in this paper were performed within the framework of the EUCAARI project (Kulmala et al., 2011). Four key regions outside Europe were chosen to perform at least 1 year of Raman lidar measurements for greater insight into aerosol effects on global climate. Apart from the South African measurements (Laakso et al., 2012), measurements took place in the Amazon Basin (Baars, 2012), India (Komppula, 2012) and China (Hänel, 2012).

The lidar measurement site at South Africa was located on a hill top at Elandsfontein $\left(26^{\circ} 15^{\prime} \mathrm{S}, 29^{\circ} 26^{\prime} \mathrm{E}, 1745 \mathrm{~m}\right.$ a.s.1.) in the Highveld region. The station was located approximately $150 \mathrm{~km}$ east from the Johannesburg-Pretoria megacity, which is the largest metropolitan area in South Africa with a population of over 10 million people (Lourens et al., 2012).

One significant source of atmospheric pollutants in the region is biomass burning through wildfires and agricultural fires (Tummon et al., 2010; Swap et al., 2003). In addition, the burning of solid fuels such as wood, dung and residual crops for domestic cooking and heating is also an important source of emissions into the atmosphere in southern Africa. These emissions (from wildfires and domestic burning), when transported above their boundary layer, are difficult to distinguish from one another. Marufu et al. (2000) have estimated that household emissions account for at least wildfire burning and industrial emissions. Another source of aerosols in the investigated region is pollution from industrialized regions in South Africa. The major industrial pollution sources within a $50 \mathrm{~km}$ radius of the measurement site include 10 coal-fired power plants, a petrochemical plant and 
some metallurgical plants (Laakso et al., 2012). Desert dust aerosols emitted from Botswana and Namibia deserts might be also possible sources of aerosols in this region. The short distance from the Indian Ocean is approximately $350 \mathrm{~km}$, therefore marine air masses can also have an impact on atmospheric aerosols at Elandsfontein.

A dominant characteristic of the South African Highveld climate is the variation between wet (October to March) and dry (April to September) periods. Approximately $90 \%$ of the annual precipitation falls during the wet period. The limited cloud cover during the dry season results in strong nocturnal inversions and reduced vertical mixing at nighttime (Laakso et al., 2012), while during daytime strong surface heating and thus vertical mixing occurs. In contrast, the cloudiness and precipitation increase dramatically during the rainy season.

There are variations in the definition of climatic seasons in South Africa since South Africa does not really experience four distinct seasons. According to actual weather conditions, spring can be rather short, lasting only 2 months, while the summer is usually relatively long. In this study we accept the definition used in Tyson and Preston-Whyte (2004): each season lasts for a period of 3 months with summer being from December to February, autumn from March to May, winter from June to August and spring from September to November. In addition, we present statistical results for the wet and dry periods, as well as for the "intense" biomass burning period (August to October).

In this study we summarize 1 year of Raman lidar observations over South Africa. The analyses of lidar measurements presented here could assist in bridging existing gaps on the knowledge of vertical distribution of aerosols above South Africa, since limited long-term data of this type are available for this region. For the first time, we have been able to cover the full seasonal cycle of geometrical characteristics and optical properties of free tropospheric aerosol layers in the region.

A description of the instrumentation and the data processing used in this study is presented in Sect. 2. The geometrical characteristics and AOD of free-tropospheric aerosol layers as well as the intensive and extensive optical properties of the layers are discussed in Sect. 3. The paper ends with a summary and conclusions in Sect. 4.

\section{Instrumentation and methodology}

\subsection{Multi-wavelength Raman lidar}

A multi-wavelength Raman lidar Polly XT (Althausen et al., 2009) supplied by the Finnish Meteorological Institute (FMI) was operated remotely at Elandsfontein in South Africa. Polly ${ }^{\mathrm{XT}}$ works with a Nd:YAG laser emitting at its primary wavelength of $1064 \mathrm{~nm}$, which, after doubling and tripling the frequency, emits at the wavelengths of 532 and $355 \mathrm{~nm}$, respectively. The receiver consists of a Newtonian telescope with a diameter of $300 \mathrm{~mm}$ and a field of view of $1 \mathrm{mrad}$. Photomultiplier tubes are used for the detection of the elastically backscattered photons at 355, 532 and $1064 \mathrm{~nm}$, as well as the in-elastically backscattered photons at 387 and $607 \mathrm{~nm}$ which correspond to the Raman-shift by nitrogen molecules at 355 and $532 \mathrm{~nm}$, respectively. Additionally, the cross-polarized component at $355 \mathrm{~nm}$ is detected for the determination of the linear particle depolarization ratio. The vertical resolution is $30 \mathrm{~m}$ and the raw data are typically stored as average values calculated over $30 \mathrm{~s}$. Data were collected on the web page of PollyNet (http://polly.tropos.de) where the "quicklooks" of all measurements are available.

The relative errors in the nighttime aerosol products are mainly determined by signal noise. Systematic uncertainties introduced by the correction of Rayleigh scattering, air density and overlap effects are of the order of 5-10\% for heights above $500 \mathrm{~m}$. The overall relative errors of the lidar-derived aerosol properties are in the range of $5-15 \%$ for backscatter coefficients, $10-30 \%$ for extinction coefficients, $15-40 \%$ for lidar ratios and about 5-10\% for AODs (Ansmann et al., 1992; Hänel et al., 2012).

The Polly ${ }^{X T}$ of FMI had also been deployed in a longterm aerosol experimental campaign at Gual Pahari, India (March 2008-March 2009) (Komppula et al., 2012) and is currently operating at Vehmasmäki, Finland $\left(62^{\circ} 44^{\prime} 17^{\prime \prime} \mathrm{N}\right.$, $27^{\circ} 32^{\prime} 33.5^{\prime \prime} \mathrm{E}, 190 \mathrm{~m}$ a.s.1.). The lidar system has been recently upgraded (Engelmann et al., 2012) and is now part of the European Aerosol Research Lidar Network (EARLINET) (Bösenberg et al., 2003; Pappalardo, et al., 2014) and the Finnish lidar network (Hirsikko et al., 2014).

\subsection{Auxiliary data}

Moderate Resolution Imaging Spectroradiometer (MODIS) collection 5 active fire product data were used in this study to determine the number of wildfire hotspots in the region (Roy et al., 2008). Hotspots is a satellite data product that has been widely used for mapping fire occurrence and is derived from temperature anomalies registered by the middle and thermal infrared sensors (Hantson et al., 2013).

Basic meteorological parameters were measured with a Vaisala WXT510 meteorological station at the site (WXT510 specification sheet, 2010, www.campbellsci.com/wxt510). Measurements included wind direction and speed with an acoustic anemometer, as well as temperature, relative humidity and rain density (Laakso et al., 2012).

\subsection{Lidar data evaluation}

Lidar measurements started on 11 December 2009 and were performed until 31 January 2011. The measurements were carried out continuously, with the exception of two periods during which maintenance was performed, i.e. from 23 December 2009 to 26 January 2010 and from 23 October 2010 to 23 November 2010. Polly ${ }^{\mathrm{XT}}$ collected measurements on 
310 days for a total of $4935 \mathrm{~h}$. In order to determine the optical profiles, the data were hourly averaged every 3 hours, i.e. leaving a gap of 2 hours between individual averaged measurements, when the atmospheric conditions were homogeneous and free of low- and medium-height clouds. The detection of low- or medium-height clouds was based on the range-corrected signal which gets totally attenuated within the first height bins above the cloud base. Only nighttime measurements are analysed in this study since Raman signals are too weak to be detected with the Polly ${ }^{\mathrm{XT}}$ during daytime. The main objective is to study the extensive (backscatter and extinction coefficients) and intensive (lidar ratio, Ångström exponents) optical properties of free-tropospheric aerosol layers in the region. The extinction and the backscatter coefficient profiles at 355 and $532 \mathrm{~nm}$ have been obtained with the Raman method (Ansmann et al., 1992), while the backscatter at $1064 \mathrm{~nm}$ has been determined using the Klett method (Klett, 1981). An overlap correction has been applied on the basis of a simple technique proposed by Wandinger and Ansmann (2002). The depolarization ratio profiles are not analysed in this study. The range-resolved elastic backscatter signal contains information that can be used to derive the height of aerosol layers. The gradient method was applied to determine the bottom and top layer heights of the aerosols in the free troposphere (Flamant et al., 1997; Bösenberg et al., 2003; Mattis et al., 2008). In general, the local maximum in the first derivative of backscatter at $1064 \mathrm{~nm}$ is considered to be the bottom of a layer, while the local minimum is considered to be the top of the layer. In order to verify the gradient method, we checked whether the layer boundaries identified by the gradient method coincide with the bottom and top heights that we recognize in coherent structures of the height time displays of the range-corrected lidar signal.

In this work we analysed the geometrical characteristics of the free tropospheric aerosol layers above the measurement site. Layers observed inside the boundary layer are not analysed in this study. The top of the planetary boundary layer (PBL) was determined as presented by Korhonen et al. (2014). PBL top heights were retrieved from the lidar backscatter signal at $1064 \mathrm{~nm}$ using the Wavelet Covariance Transform method (Brooks, 2003). The accuracy on geometrical boundaries identification of free-tropospheric aerosol layers depends on the correct determination of PBL top height. Korhonen et al. (2014) have shown that the Wavelet Covariance Transform method performs well despite the frequent complex vertical aerosol layer structures caused by large emissions from large point sources and biomass burning. Subsequently, 7-day back-trajectories were calculated by means of the HYSPLIT model (Draxler and Hess, 1997, 1998) for the centre height of each elevated layer.

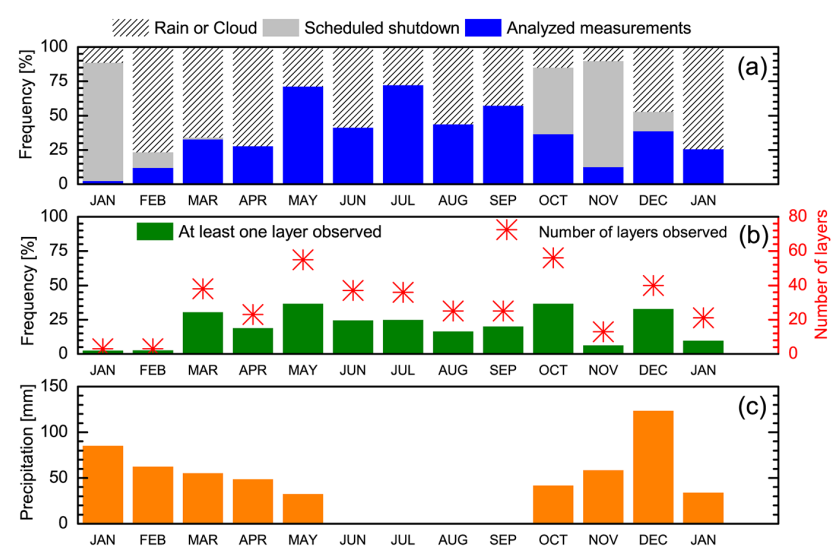

Figure 1. (a) Percentage of nighttime analysed measurements, scheduled shutdown and unanalysed measurements ("no measurements") due to weather conditions (rain or clouds); (b) the percentage of measurements in which free-tropospheric aerosol layers were observed (green bars) and the total number of the observed layers (red stars) per month; (c) monthly accumulated precipitation at Elandsfontein.

\section{Results and discussion}

The percentage of the nighttime measurements performed each month in terms of hourly averaged profiles every 3 hours (i.e. leaving a gap of 2 hours between individual averaged measurements) is presented in Fig. 1a (blue bars), which varies between 3 and $72 \%$ for all the months. The percentage was calculated by taking into account the nighttime hours for each month. Analysis could not be performed during unfavourable weather conditions, such as the presence of low clouds and rain (shaded bars) or due to the scheduled shutdowns (grey bars). In Fig. 1b we present the percentage of the measurements in which at least one free-tropospheric aerosol layer was observed (green bars) relative to the hourly averaged (every three hours) lidar measurements. The total number of the observed free-tropospheric layers per month is presented with red stars in the same figure. In total, 375 aerosol layers were observed above the boundary layer during the period studied.

In this region, approximately $90 \%$ of the annual precipitation falls during the wet season (October-March) (Laakso et al., 2012, and references therein), as indicated in Fig. 1c. Fewer measurements were performed during the wet period. The seasonal precipitation cycle should not only affect the number of measurements that could be performed but also the total number of layers observed. Therefore it is expected that the fraction of measurements of free-tropospheric aerosol layers in relation to the total number of observations should be less during the wet season due to wet scavenging. However, our results indicate that during the wet period a relatively large number of layers are still observed in the free troposphere. The general anticyclonic nature of atmospheric circulation over the region, results in the formation of ab- 
solutely stable layers of air throughout the year (Cosijn and Tyson, 1996). According to the same study the absolutely stable air layers occur preferentially at around the 700, 500 and $300 \mathrm{hPa}$ levels and are spatially extensive and temporally persistent in fair weather conditions.

\subsection{Geometrical characteristics and optical depth of free-tropospheric aerosol layers}

In order to define the geometrical boundaries of freetropospheric aerosol layers we need to determine the PBL top height. In this study the determination of PBL top height was performed for the hourly nighttime lidar observations and only for the cases which at least one layer was observed. The PBL top height is presented in Fig. 2a. The average PBL top height was found to be $1440 \pm 656 \mathrm{~m}$ a.g.l. The highest PBL top height was observed during spring (October) while lower PBL values were observed in winter. South Africa is a region of high atmospheric variability on both short-scale (days to weeks) and seasonal time spans. This atmospheric variability together with a large surface temperature range and significant seasonal changes in precipitation has an impact on the vertical mixing of particulate matter, and hence on the high variability of PBL top height as shown in Fig. 2. The diurnal cycle of PBL observed in Elandsfontein during 2010 is presented in detail by Korhonen et al. (2014).

The difference between the bottom of the first freetropospheric aerosol layer observed from the PBL height is presented in Fig. 2b. Forty five percent $(45 \%)$ of the elevated layers were separated by up to $500 \mathrm{~m}$ from the PBL aerosols. In about of $20 \%$ of the hourly analysed cases the free tropospheric layers were separated by more than $1000 \mathrm{~m}$ from the PBL height.

Figure 3 shows our complete data set of lidar measurements in terms of geometrical characteristics. The vertical lines present the observed height ranges of freetropospheric aerosol layers. Out of 429 hourly analysed lidar observation, we observe free-tropospheric aerosol layers on 223 hourly analysed observations (i.e. 52\%). In total 375 free-tropospheric aerosol layers were observed. The free-tropospheric aerosol layers are observed as a single layer on $52 \%$ of the cases, while they are often characterized by two $(32 \%)$, three $(13 \%)$ or more particle layers (3\%). Up to five layers were observed simultaneously. The maximum top height observed was $5730 \mathrm{~m}$ a.g.l. on 22 August 2010, while the minimum bottom height was $400 \mathrm{~m}$ a.g.l. and observed on 21 July 2010. The geometrical depth of the free tropospheric layers varies from a few hundred metres to several kilometres throughout the period under investigation. Figure 3 already indicates that layers are observed at higher elevation levels during the second half of the year.

The analysed hourly centre height, geometrical depth and AOD at 355 and $532 \mathrm{~nm}$ are monthly averaged and presented in Fig. $4 \mathrm{a}-\mathrm{c}$ respectively. The AOD measured is the integrated extinction coefficients at 355 and $532 \mathrm{~nm}$ for each
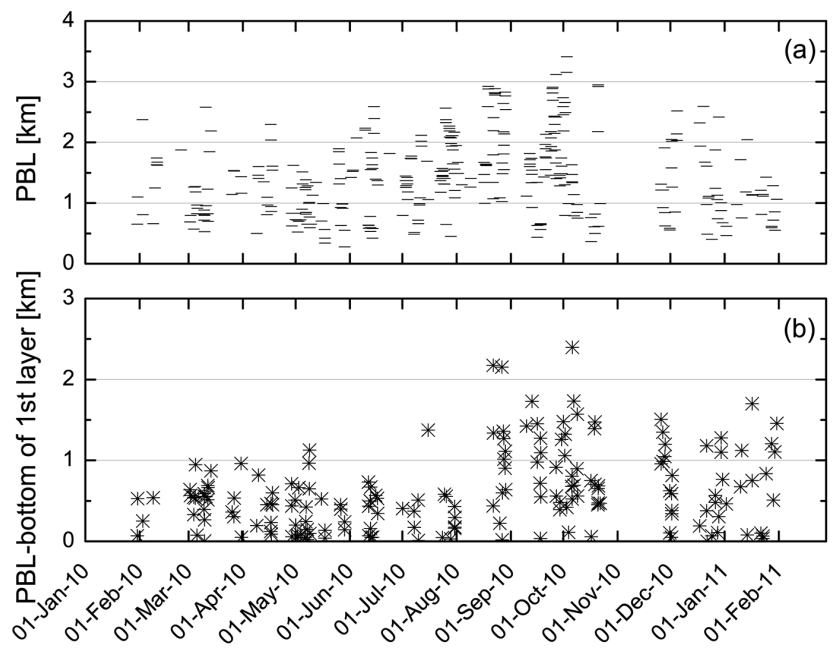

Figure 2. The hourly planetary boundary layer (a) and the difference between the bottom of the first free-tropospheric layer observed and the planetary boundary (b) observed between 30 January 2010 and 31 January 2011.

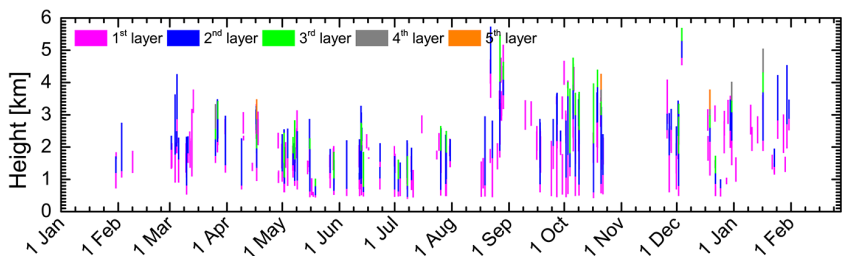

Figure 3. Geometrical boundaries of free-tropospheric aerosol layers observed between 30 January 2010 and 31 January 2011.

layer identified. From the total number of free-tropospheric layers observed, $72 \%$ occurred at heights higher than $1500 \mathrm{~m}$ a.g.l. The higher and thicker layers were observed during the second half of the year. According to the MODIS fire product in year 2010 the biomass burning activity started in July and lasted until October (https://firms.modaps.eosdis. nasa.gov/animations/2010_animation.gif), which is a typical seasonal pattern in southern Africa (e.g. Ito et al., 2007). The increase in biomass burning activity most probably contributes to higher and more frequent aerosol layer observations from August to October. During winter a surface inversion layer extends from the ground up to $300 \mathrm{~m}$ above the surface. An absolutely stable layer at $3000 \mathrm{~m}$ above sea level is also present in $90 \%$ of days during winter (Cosijn and Tyson, 1996). The effective height of the power station stacks are around $400 \mathrm{~m}$ (http://www.eskom.co.za). So, during winter nights aerosol layer plumes can be trapped between the surface layer and the absolutely stable layer.

Due to low signal-to-noise ratios, analysis of the optical properties could not be performed for the entire data set. For this reason the number of geometrically observed layers (Fig. 4a) is larger (or equal) than the number of layers for which layer AOD could be calculated (squares in Fig. 4c). 

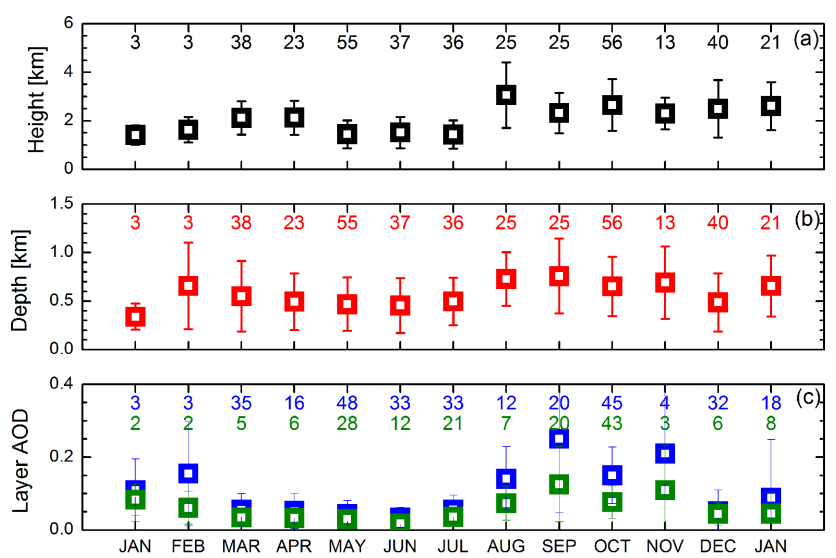

Figure 4. Geometrical characteristics and optical properties of free tropospheric aerosol layers observed between 30 January 2010 and 31 January 2011. From top to bottom: the centre height of the layers observed (a), the geometrical depth of the layers observed (b), aerosol optical depths at 355 (blue) and $532 \mathrm{~nm}$ (green) (c). The number of free tropospheric aerosol layers averaged is also presented in the top of each figure.

Mean extinction coefficient and thus layer AOD show large variations both at 355 and $532 \mathrm{~nm}$. On average, aerosol layer optical depths at both wavelengths were below 0.1. Only during late winter and spring was the mean AOD of free tropospheric layers at $355 \mathrm{~nm}$ above 0.1 . Maximum values of layer AOD up to 0.3 at both wavelengths were reached, which is a significant (of the order of $85 \%$ ) contribution to the columnar AOD. During May and June large extinction coefficients are observed for the lower layers. However, the corresponding AODs are low due to small geometrical depths of these layers.

In order to further investigate the contribution of the freetropospheric aerosol load to the columnar AOD we studied the columnar, free-tropospheric and boundary layer AODs in more detail. For each of the lidar measurements analysed, columnar AOD estimates were determined by integrating the aerosol extinction coefficient at $355 \mathrm{~nm}$ and $532 \mathrm{~nm}$. We assumed that the extinction value at the height for which the overlap function is equal to 0.7 is representative down to the surface to account for the incomplete overlap region. The value of 0.7 is reached between 300 and $500 \mathrm{~m}$. Therefore, this is a reasonable assumption and it is also a common approach in lidar studies (e.g. Giannakaki et al., 2010). In Fig. 5 we present the columnar AOD calculated from each of the hourly analysed lidar measurements at 355 (a) and $532 \mathrm{~nm}$ (b). In the same figure sun photometer daily values are presented for 340 and $380 \mathrm{~nm}$ (a) as well as for $500 \mathrm{~nm}$ (b). The mean columnar AOD obtained from lidar measurements was found to be $0.46 \pm 0.35$ at $355 \mathrm{~nm}$ and $0.25 \pm 0.2$ at $532 \mathrm{~nm}$. The direct comparison of the two data sets is not the purpose of this study since sun photometer values are referring to daytime measurements while lidar
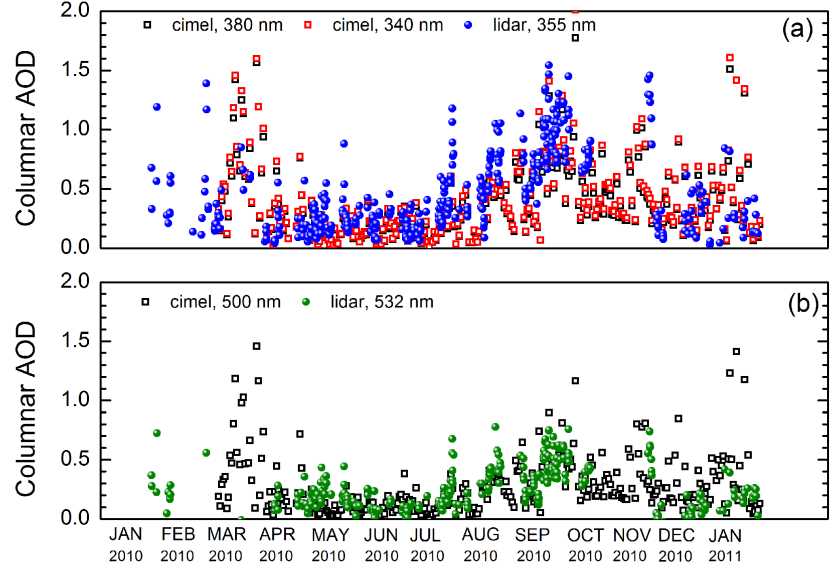

Figure 5. Columnar optical depth at ultraviolet (a) and visible (b) wavelengths. Open squares correspond to cimel daily mean values while filled circles correspond to hourly nighttime lidar values.

data are nighttime measurements. The lidar-derived columnar AOD exhibits a seasonal variability, with maximum values of 1.54 and 0.78 at 355 and $532 \mathrm{~nm}$, respectively, measured in late September. The same seasonal behaviour is also observed with sun photometer.

In an effort to explain the observed seasonality of the columnar AOD, we separately estimated the AOD in the boundary layer and the free troposphere at $355 \mathrm{~nm}$, which are presented in Fig. 6a. As can be seen in Fig. 6a, the same seasonal pattern is observed for the AOD at $355 \mathrm{~nm}$ in the boundary layer and the free troposphere, i.e. larger AOD values are measured during late July, August, September and October in the boundary layer and the free troposphere. This is also found for the AOD at $532 \mathrm{~nm}$ (not shown here). In Fig. $6 \mathrm{~b}$ we present the percentage contribution of free tropospheric AOD to the total AOD. Large variations of the contribution of free-tropospheric AOD to the total AOD are observed for the period investigated, with a mean value of $46 \%$. The largest monthly contribution of $58 \%$ is observed in October. The period with increases in columnar, free-tropospheric and boundary layer AODs coincides with higher wind speeds as presented in Fig. 7a and an increase in biomass burning activity in South Africa shown in Fig. 7b. Tesfaye et al. (2011) attributed the increase of columnar AODs mainly to local sources and enhanced wind speeds. Higher wind speeds could lead to an increased transport of biomass emissions from regions further away from Elandsfontein. The increase in biomass burning activity in South Africa also contributes to enhance free tropospheric AOD. This is supported by the higher altitude of the observed aerosol layers during August, September and October (Fig. 3). The number of hotspots (http://earthdata.nasa. gov/data/nrt-data/firms/active-fire-data) observed in the latitude range between 40 and $20^{\circ} \mathrm{S}$ and longitude range between 20 and $40^{\circ} \mathrm{E}$ degrees is plotted in Fig. $7 \mathrm{~b}$. The re- 

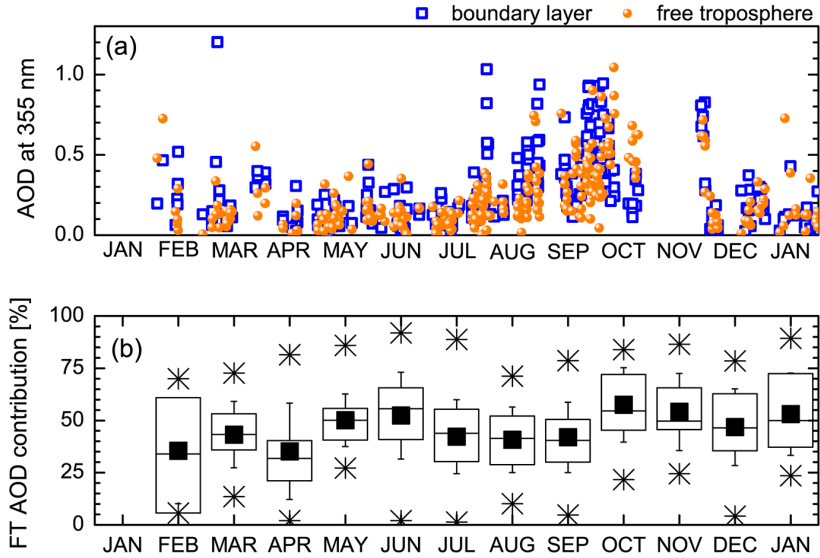

Figure 6. Variation of AOD at $355 \mathrm{~nm}$ (a) of the boundary layer (blue squares) and the free troposphere (orange circles) and (b) the monthly free tropospheric contribution to total AOD at $355 \mathrm{~nm}$. In (b) the squares represent the mean value, the horizontal line the median, the boxes the 25 and $75 \%$ percentiles, the whiskers the standard deviation and the stars the maximum and minimum values during the respective month.

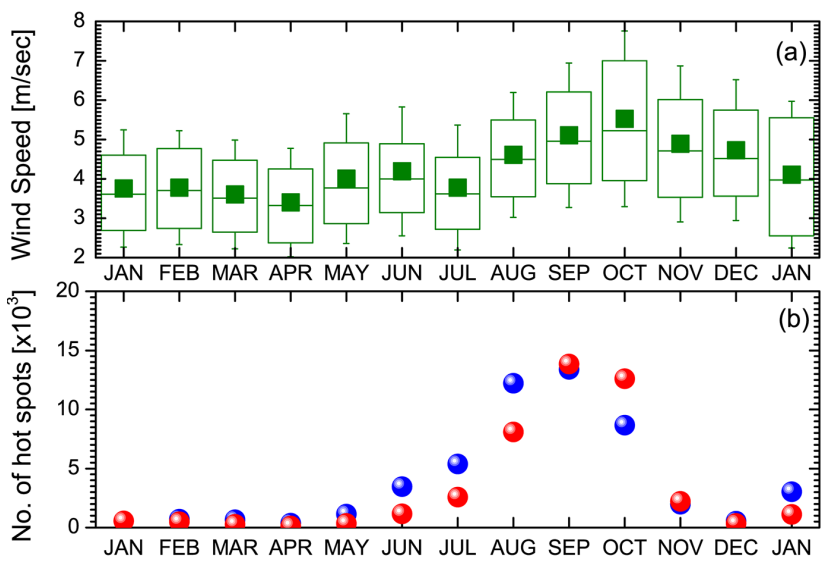

Figure 7. (a) Monthly variation of wind speed: the squares represent the mean value, the horizontal line the median, the boxes the 25 and $75 \%$ percentiles and the whiskers the 1 standard deviation. (b) Number of hotspots over the region lat $\left(40,20^{\circ} \mathrm{S}\right)$ and long (20, $40^{\circ} \mathrm{E}$ ) with medium (blue) and high (red) confidence level.

sults are presented in two clusters of medium (30-80\%) and high confidence (80-100\%) (https://earthdata.nasa.gov/data/ near-real-time-data/firms/about). The number of hotspots with high confidence, in the region under study, ranges from 10000 to 15000 during August, September and October; while it is less than 2000 for the rest of the months.

Histograms of the geometrical centre height of the lofted particle plumes with bin intervals of $750 \mathrm{~m}$ are shown in Fig. 8 for each of the seasons. In the same figure, the statistical distribution for each season is also presented with box and whisker plots. High variation in the geometrical characteristics is observed throughout the year. Mean values of ge-
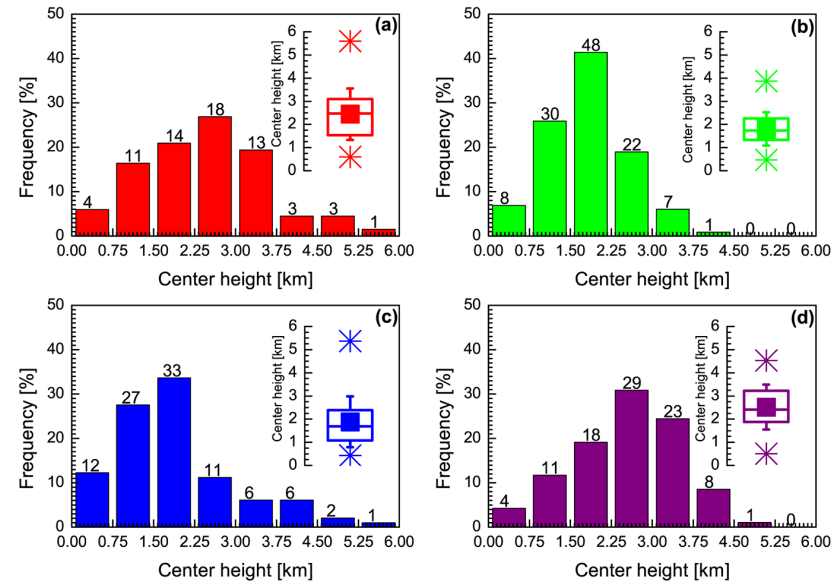

Figure 8. Frequency distribution of centre height of freetropospheric aerosol layers in South Africa between 30 January 2010 and 31 January 2011, for (a) summer, (b) autumn, (c) winter and (d) spring. Box and whisker plots are also presented for each of the seasons: filled square is the mean value, horizontal line is the median, boxes are the 25 and $75 \%$ percentiles respectively, whiskers represent the 1 standard deviation and stars the minimum and maximum values.

ometrical centres, as well as AODs at 355 and $532 \mathrm{~nm}$ are presented in Table 1. In general, free-tropospheric aerosol layers were found at higher altitudes in spring and summer. The peak of the frequency distribution of the geometrical mean height of the observed free-tropospheric aerosol layers during spring and summer were found to be between 2250 and $3000 \mathrm{~m}$ a.g.l., while for autumn and winter the peak ranges between 1500 and $2250 \mathrm{~m}$ a.g.l. Only $35 \%$ of the analysed free-tropospheric aerosol layers were observed below $2250 \mathrm{~m}$ a.g.l. during spring, while in summer, autumn and winter 43,74 , and $75 \%$ of the free-tropospheric aerosol layers were observed below $2250 \mathrm{~m}$, respectively. The higher free-tropospheric aerosol layers during spring is possibly due to intensive biomass burning activity in central and southern Africa and the transport of smoke above our measurement site. Seven-day back-trajectory analysis together with superimposed hotspots derived by MODIS for each of the layers identified reveals long-range transport of biomass burning aerosols over Elandsfontein in most of the cases analysed during spring.

\subsection{Extensive and intensive optical properties of free-tropospheric aerosol layers}

Detailed statistical information on the extensive aerosol properties is presented in Table 2. It is evident that a wide range of extinction and backscatter coefficients for the four seasons during the year is observed. In addition to seasonal values we also present the values for wet, dry and biomass burning periods. 
Table 1. Geometrical characteristics and AOD at 355 and $532 \mathrm{~nm}$ of free tropospheric aerosols for summer, autumn, winter, spring, wet, dry and biomass burning period. The values represent the mean value and 1 standard deviation. The numbers in brackets are the median value. The numbers in parentheses are the number of free-tropospheric aerosol layers averaged.

\begin{tabular}{lrrr}
\hline Season or period & Centre $(\mathrm{m})$ & AOD 355 nm & AOD 532 nm \\
\hline Summer (Dec-Feb) & $2440 \pm 1100(67)[2470]$ & $0.07 \pm 0.11(56)[0.03]$ & $0.05 \pm 0.04(18)[0.04]$ \\
Autumn (Mar-May) & $1800 \pm 720(116)[1740]$ & $0.05 \pm 0.04(99)[0.04]$ & $0.03 \pm 0.02(39)[0.02]$ \\
Winter (Jun-Aug) & $1880 \pm 1100(98)[1685]$ & $0.06 \pm 0.06(78)[0.04]$ & $0.04 \pm 0.04(40)[0.03]$ \\
Spring (Sep-Nov) & $2520 \pm 970(94)[2415]$ & $0.18 \pm 0.14(69)[0.15]$ & $0.09 \pm 0.07(66)[0.08]$ \\
Wet (Oct-Mar) & $2430 \pm 1000(174)[2375]$ & $0.10 \pm 0.10(140)[0.06]$ & $0.07 \pm 0.05(69)[0.06]$ \\
Dry (Apr-Sep) & $1850 \pm 950(201)[1715]$ & $0.08 \pm 0.12(162)[0.04]$ & $0.05 \pm 0.06(94)[0.04]$ \\
Biomass burning (Aug-Oct) & $2670 \pm 1100(106)[2535]$ & $0.18 \pm 0.13(77)[0.15]$ & $0.09 \pm 0.07(70)[0.08]$ \\
\hline
\end{tabular}

Table 2. Extensive optical properties of free-tropospheric aerosol layers for summer, autumn, winter, spring, wet period, dry period and biomass burning period. The values represent the mean value and 1 standard deviation. The numbers in brackets are the median value. The numbers in parentheses are the number of free-tropospheric aerosol layers averaged.

\begin{tabular}{lrrrrr}
\hline $\begin{array}{l}\text { Season or } \\
\text { period }\end{array}$ & $\begin{array}{r}\text { Bsc. coef. } \\
\text { 355 } \mathrm{nm}\left(\mathrm{Mm}^{-1} \mathrm{sr}^{-1}\right)\end{array}$ & $\begin{array}{r}\text { Bsc. coef. } \\
532 \mathrm{~nm}\left(\mathrm{Mm}^{-1} \mathrm{sr}^{-1}\right)\end{array}$ & $\begin{array}{r}\text { Bsc. coef. } \\
1064 \mathrm{~nm}\left(\mathrm{Mm}^{-1} \mathrm{sr}^{-1}\right)\end{array}$ & $\begin{array}{r}\text { Ext. coef. } \\
355 \mathrm{~nm}\left(\mathrm{Mm}^{-1}\right)\end{array}$ & $\begin{array}{r}\text { Ext. coef. } \\
532 \mathrm{~nm}\left(\mathrm{Mm}^{-1}\right)\end{array}$ \\
\hline Summer & $2.7 \pm 6.0(62)[1.3]$ & $1.0 \pm 1.0(52)[0.6]$ & $0.7 \pm 2.0(62)[0.2]$ & $118 \pm 142(56)[67]$ & $82 \pm 69(18)[47]$ \\
Autumn & $1.6 \pm 1.0(109)[1.3]$ & $1.0 \pm 0.8(54)[0.8]$ & $0.4 \pm 0.2(111)[0.3]$ & $97 \pm 65(99)[77]$ & $63 \pm 36(39)[63]$ \\
Winter & $1.8 \pm 1.3(80)[1.5]$ & $1.2 \pm 1.0(44)[1.0]$ & $0.5 \pm 0.4(81)[0.4]$ & $115 \pm 93(78)[83]$ & $80 \pm 55(40)[64]$ \\
Spring & $2.7 \pm 1.3(71)[2.6]$ & $1.5 \pm 0.8(71)[1.3]$ & $0.6 \pm 0.4(71)[0.6]$ & $232 \pm 95(69)[229]$ & $118 \pm 51(66)[113]$ \\
Wet & $2.4 \pm 3.7(149)[1.8]$ & $1.2 \pm 0.9(112)[1.0]$ & $0.6 \pm 1.3(149)[0.4]$ & $147 \pm 118(140)[125]$ & $98 \pm 52(69)[91]$ \\
Dry & $1.8 \pm 1.3(173)[1.5]$ & $1.2 \pm 1.0(109)[1.0]$ & $0.5 \pm 0.4(176)[0.4]$ & $127 \pm 102(162)[93]$ & $87 \pm 58(94)[73]$ \\
Biomass & $2.6 \pm 1.2(79)[2.5]$ & $1.5 \pm 0.8(74)[1.3]$ & $0.7 \pm 0.4(79)[0.6]$ & $225 \pm 88(77)[223]$ & $117 \pm 47(70)[113]$ \\
\hline
\end{tabular}

Mean Ångström exponents and lidar ratios were derived for the observed geometrical layers when the extinction and backscatter coefficients profiles could be obtained. The monthly averaged lidar ratio at 355 and $532 \mathrm{~nm}$, as well as the Ångström exponents of free tropospheric layers are presented in Fig. 9.

Between late winter and throughout spring high lidar ratios are observed at both wavelengths. During this period a significant number of aerosol layers originate from wildwire and controlled fires. Although these fire plumes occur at ground level, they are lifted higher in the atmosphere due to the increased heat and may be transported above Elandsfontein. Domestic biomass burning in informal settlements for cooking and heating can also contribute, but these emissions are exclusively emitted at ground level. It is therefore unlikely that such emission close to Elandsfontein will have a significant impact to free-tropospheric aerosol load measured. However, household emissions are common across the entire southern Africa, which implies that regional transport of such emission further away from Elandsfontein may result in a contribution to the free-tropospheric load measured over Elandsfontein. The absorbing smoke aerosols, originating from all the aforementioned combustion sources, can explain the large lidar ratio values observed. During this period the Ångström exponents appear to have large variation, with smaller values observed for lower aerosol layers. Ångström
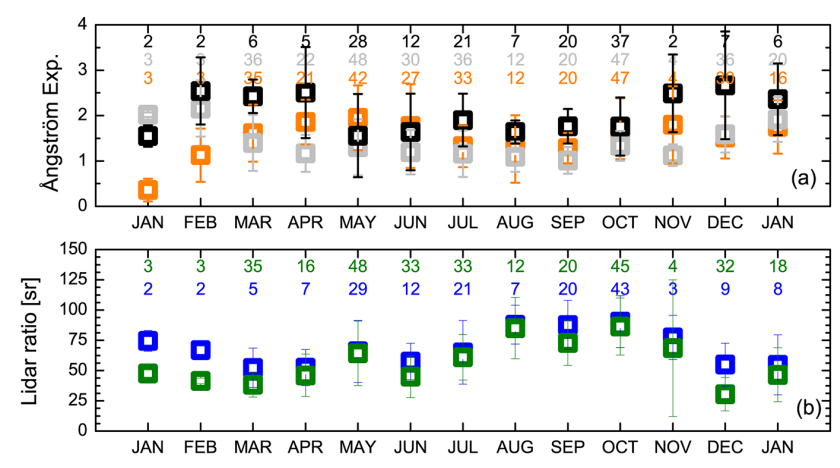

Figure 9. Intensive layer properties of the free-tropospheric aerosol layers observed between 30 January 2010 and 31 January 2011. From top to bottom: (a) Ångström exponent related to backscatter between 355 and $532 \mathrm{~nm}$ (grey), related to backscatter between 532 and $1064 \mathrm{~nm}$ (orange) and related to extinction between 355 and $532 \mathrm{~nm}$ (black) and (b) lidar ratio at 355 (blue) and $532 \mathrm{~nm}$ (green).

exponents appear to be lower from May to September. This can be attributed to the lower precipitation (dry season). Therefore larger particles stay longer in the atmosphere at lower layers, since they are not washed out. Also, particles can grow through accumulation during the dry season resulting in lower Ångström exponents. 
Table 3. Intensive optical properties of free-tropospheric aerosol layers for summer, autumn, winter, spring, wet period, dry period and biomass burning period. The values represent the mean value and 1 standard deviation. The numbers in brackets are the median value. The numbers in parentheses are the number of free-tropospheric aerosol layers averaged.

\begin{tabular}{lrrrrr}
\hline $\begin{array}{l}\text { Season or } \\
\text { period }\end{array}$ & $\begin{array}{r}\text { Lidar ratio } \\
355 \mathrm{~nm}(\mathrm{sr})\end{array}$ & $\begin{array}{r}\text { Lidar ratio } \\
532 \mathrm{~nm}(\mathrm{sr})\end{array}$ & $\begin{array}{r}\text { Ångström exp. } \\
\mathrm{b}_{355} / \mathrm{b}_{532}\end{array}$ & $\begin{array}{r}\text { Angström exp. } \\
\mathrm{b}_{532} / \mathrm{b}_{1064}\end{array}$ & $\begin{array}{r}\text { Ånström exp. } \\
\alpha_{355} / \alpha_{532}\end{array}$ \\
\hline Summer & $57 \pm 20(56)[59]$ & $39 \pm 18(21)[31]$ & $1.5 \pm 0.6(52)[1.5]$ & $1.7 \pm 0.5(62)[1.7]$ & $2.4 \pm 0.9(17)[2.3]$ \\
Autumn & $59 \pm 22(99)[54]$ & $58 \pm 26(41)[53]$ & $1.8 \pm 0.7(98)[1.8]$ & $1.3 \pm 0.6(106)[1.2]$ & $1.8 \pm 0.9(39)[1.9]$ \\
Winter & $65 \pm 23(78)[64]$ & $60 \pm 23(40)[60]$ & $1.5 \pm 0.7(72)[1.3]$ & $1.2 \pm 0.5(78)[1.1]$ & $1.8 \pm 0.6(40)[1.8]$ \\
Spring & $89 \pm 21(69)[86]$ & $82 \pm 25(66)[81]$ & $1.6 \pm 0.6(71)[1.4]$ & $1.2 \pm 0.3(71)[1.2]$ & $1.8 \pm 0.6(59)[1.8]$ \\
Wet & $67 \pm 26(140)[66]$ & $69 \pm 32(72)[64]$ & $1.6 \pm 0.6(138)[1.5]$ & $1.5 \pm 0.5(149)[1.4]$ & $2.0 \pm 0.8(62)[2.0]$ \\
Dry & $67 \pm 24(162)[64]$ & $63 \pm 24(96)[61]$ & $1.6 \pm 0.7(155)[1.6]$ & $1.2 \pm 0.5(168)[1.1]$ & $1.8 \pm 0.7(93)[1.8]$ \\
Biomass & $89 \pm 20(77)[87]$ & $83 \pm 23(70)[81]$ & $1.5 \pm 0.6(79)[1.4]$ & $1.2 \pm 0.3(79)[1.2]$ & $1.8 \pm 0.5(64)[1.8]$ \\
\hline
\end{tabular}
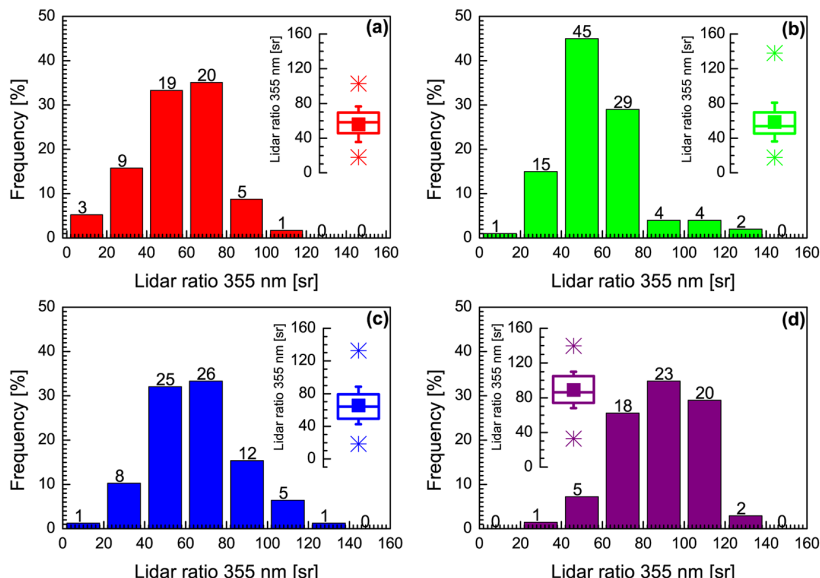

Figure 10. Frequency distribution of lidar ratio at $355 \mathrm{~nm}$ of free tropospheric aerosol layers in South Africa between 30 January 2010 and 31 January 2011, for (a) summer, (b) autumn, (c) winter and (d) spring. Box and whisker plots are also presented for each of the seasons: filled square is the mean value, horizontal line is the median, boxes are the 25 and $75 \%$ percentiles respectively, whiskers represent the one standard deviation and stars the minimum and maximum values.

The seasonal frequency distribution plots for the lidar ratio at $355 \mathrm{~nm}$ and the Ångström exponent related to extinction between 355 and $532 \mathrm{~nm}$ are presented in Figs. 10 and 11, respectively. We present the frequency distribution plot only for $355 \mathrm{~nm}$ because observation of the lidar ratio at $532 \mathrm{~nm}$ was more often limited due to detector problems. Additional information on the intensive optical properties for both wavelengths is given in Table 3 . The values in the table represent the mean value and one standard deviation. The numbers in brackets are the median value, while the number in parentheses are the number of free-tropospheric aerosol layers averages in each season (summer, autumn, winter, spring) or period (wet, dry, biomass). An average lidar ratio of $67 \pm 25 \mathrm{sr}$ at $355 \mathrm{~nm}$ and a mean extinction-related Ångström exponent of $1.9 \pm 0.8$ between 355 and $532 \mathrm{~nm}$ are measured during the entire sampling period in South Africa.
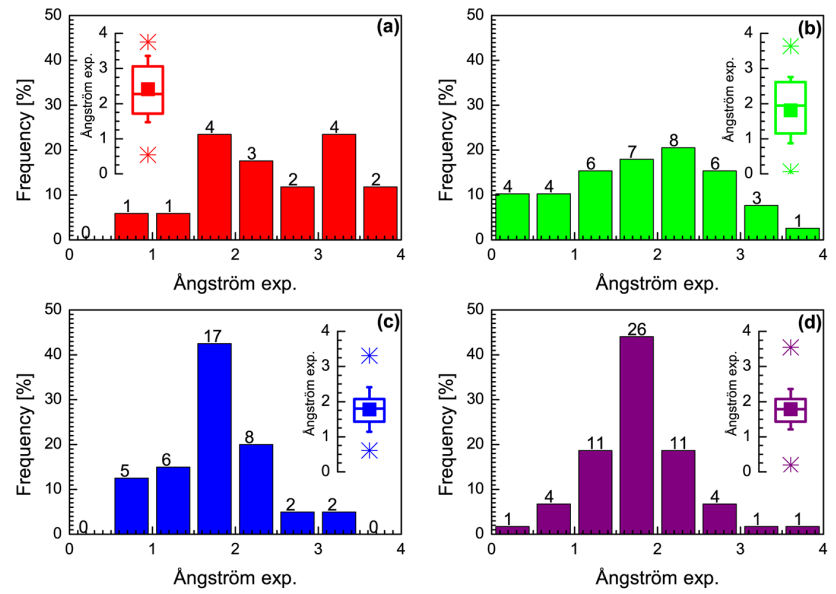

Figure 11. Frequency distribution of extinction related Ångström exponent between 355 and $532 \mathrm{~nm}$ of free-tropospheric aerosol layers in South Africa between 30 January 2010 and 31 January 2011, for (a) summer, (b) autumn, (c) winter and (d) spring. Box and whisker plots are also presented for each of the seasons: filled square is the mean value, horizontal line is the median, boxes are the 25 and $75 \%$ percentiles respectively, whiskers represent the 1 standard deviation and stars the minimum and maximum values.

Lower mean values of lidar ratio and larger Ångström exponents have been observed during summer. One possible explanation is the removal of larger aerosols through wetscavenging during these wetter months. Most of the freetropospheric aerosol layers observed during this period were associated with an easterly air mass flow. The major industrial pollution sources are located primarily either to the north, west or southwest of the lidar at Elandsfontein (Laakso et al., 2012). Therefore, the easterly flow that prevails during summer results in a less polluted free troposphere, compared to other seasons. Aerosols measured during this period could also include maritime aerosols with air masses moving from the Indian Ocean.

However, we should note that during summer the Ångström exponent related to backscatter between 355 and 
$532 \mathrm{~nm}$ is $1.5 \pm 0.6$ much smaller than Ångström exponent related to extinction in the same wavelength range which is $2.4 \pm 0.9$. The number of averaged layers to derive the Ångström exponent related to extinction during summer is 17, and for Ångström exponent related to backscatter is 52 . For this reason we select only those layers, for which all five intensive optical properties were retrieved (15). Significant spectral dependence of the lidar ratio values during summer is observed which results in quite different values of Ångström exponent related to backscatter and Ångström exponent related to extinction values. The mean ratio of lidar ratio between 355 and $532 \mathrm{~nm}$ is $0.64 \pm 0.23$ during summer, while it is larger and close to 1 for the rest of the seasons (autumn: $0.96 \pm 0.3$; winter: $0.82 \pm 0.21$, spring: $0.94 \pm 0.29$ ). The results during summer must be considered to be only indicative since the number of aerosol layers averaged during summer is only 15 (less than half compared to other seasons). More data should be collected and analysed for a more accurate conclusion.

The frequency distribution plots of lidar ratio for autumn and winter are quite similar. However, $16 \%$ of elevated aerosols during autumn are associated with lidar ratios lower than $40 \mathrm{sr}$, while $12 \%$ of lidar ratios were lower than $40 \mathrm{sr}$ during winter. Seven-day backward trajectory analysis clearly indicated that these aerosol plumes (with lidar ratio lower than $40 \mathrm{sr}$ ) passed above the ocean at low heights. Wildfires in late July and August (see Fig. 7b) are the main sources of absorbing smoke aerosols that result in aerosol layer plumes with high lidar ratios during these months. The intensive biomass burning activity in South Africa during spring is clearly reflected in the frequency distribution of the lidar ratio at $355 \mathrm{~nm}$ indicated by larger lidar ratio values, with a peak between 80 and 100 sr.

The frequency distribution plots of the extinction related Ångström exponent between 355 and $532 \mathrm{~nm}$ in Fig. 11 reveal relatively evenly spread values during summer and autumn with no specific peak. This can most likely be attributed to atmospheric mixing processes. Ångström exponent distribution plot during winter and spring are similar, with a narrow distribution around 1.75 .

\subsection{Comparison with prior studies}

This study is the first long-term lidar study of intensive and extensive optical aerosol properties in South Africa. Large variability is observed both for lidar ratio and Ångström exponent of free-tropospheric aerosol layers throughout the year. Several statistics of lidar ratio and Ångström exponent are available for comparison and discussion.

\subsubsection{Lidar ratio}

During spring the lidar ratio of elevated layers is high, on average $89 \mathrm{sr}$. The large lidar ratio values during this period is attributed to biomass burning aerosol layers. Mean lidar ra- tios at $355 \mathrm{~nm}$ vary from 21 to $67 \mathrm{sr}$, whereas 26 to $87 \mathrm{sr}$ is found for the lidar ratio at $532 \mathrm{~nm}$ for aged Siberian forest fire smoke (Müller et al., 2005). Giannakaki et al. (2010) analysed 7 years of EARLINET observations (2001-2007) and found lidar ratio at $355 \mathrm{~nm}$ of the order of $70 \mathrm{sr}$ for biomass burning aerosols.

During summer and autumn lidar ratio values at $355 \mathrm{~nm}$ are $57 \pm 20$ and $59 \pm 22 \mathrm{sr}$, respectively. These values are within the range of previous observation for urban/industrial aerosols (Müller et al., 2007; Giannakaki et al., 2010; Bösenberg et al., 2003). Anderson et al. (2003) found a mean lidar ratio of $45 \pm 10 \mathrm{sr}$ at $532 \mathrm{~nm}$ during the ACE-Asia campaign in the spring of 2000 for East Asian haze over the Pacific Ocean close to China. Murayama et al. (2003) analysed ACE-Asia lidar and aircraft measurements over Japan and found mean lidar ratios of 35-45 sr in the polluted lower troposphere. Bösenberg et al. (2003) report an average lidar ratio of $55 \mathrm{sr}$ at $351 \mathrm{~nm}$ for height range 2000 to $3000 \mathrm{~m}$ over Hamburg, Germany.

During winter mean lidar ratio at $355 \mathrm{~nm}$ was found equal to $65 \pm 23 \mathrm{sr}$, larger than the values for summer and autumn. These aerosol layers are attributed mainly to urban/industrial aerosols during June and July while during August the aerosol layers are possible a mixture of urban/industrial aerosols with biomass burning aerosols.

\subsection{2 Ångström exponent}

In this study we report mean Ångström exponent of $2.4 \pm 0.9,1.8 \pm 0.9,1.8 \pm 0.6$ and $1.8 \pm 0.6$ for summer, autumn, winter and spring respectively. As discussed in Sect. 3.2, the results for Ångström exponent during summer must be considered to be only indicative since the number of aerosol layers averaged during summer is limited. For the rest of the seasons the values of Angström exponent agree very well with former studies.

Murayama et al. (2003) have found Ångström exponents of 1.5-2 in the wavelength range from 450 to $428700 \mathrm{~nm}$ on the polluted lower troposphere over Japan. Giannakaki et al. (2010) have found large variation of Ångström exponent for European continental anthropogenic aerosols which was attributed to different aerosol sources.

For biomass burning aerosols Amiridis et al. (2009) found that backscatter-related Ångström exponent over southeastern Europe ranges between 0.5 and 2.4 indicating a variety of particle sizes. An Ångström exponent of 1.35 was measured for Siberian forest fire smoke at Tokyo (Murayama et al., 2004). Mean particle Ångström exponent between 355 and $532 \mathrm{~nm}$ varied from 0 to 1.3 for aged biomass burning aerosols observed over central Germany (Müller et al., 2005). Giannakaki et al. (2010) found that Ångström exponent ranges from 1 to 3 both for biomass burning aerosols and European continental polluted aerosols, indicating the same size of aerosols for these types of aerosols. 


\section{Summary and conclusions}

The seasonal patterns of the geometrical characteristics and optical properties of elevated aerosol layers at a continental site in South Africa are presented. The geometrical depth of the free-tropospheric layers varies from a few hundred metres to several kilometres. The free-tropospheric aerosol layers are observed as single layer on $52 \%$ of the cases, while they are often characterized by two (32\%), three $(13 \%)$ or more particle layers $(3 \%)$. Several aerosol sources may be responsible for a single free-tropospheric pollution event. The classification of the aerosol layers in respect to the season of occurrence revealed rather stable geometrical aerosol layer depths for winter, summer and autumn with higher aerosol layer depths during spring. During winter nights layers are observed up to $3000 \mathrm{~m}$. These aerosol layers are probably trapped between the inversion surface layer and an absolutely stable layer that is formed in $90 \%$ of days during winter (Cosijn and Tyson, 1996).

Except for the intensive biomass burning period from $\mathrm{Au}-$ gust to October, the lidar ratios and Ångström exponents are within the range of previous observations for urban/industrial aerosols (Müller et al., 2007; Giannakaki et al., 2010; Bösenberg et al., 2003). Considering that the Elandsfontein measurement station is located in the midst of large industrial plants $150 \mathrm{~km}$ east of the megacity of Johannesburg, this is reasonable. However, we observed large variability in both intensive and extensive aerosol properties of freetropospheric aerosol layers. From August to October, the lidar ratio of elevated layers is high, on average $89 \mathrm{sr}$, which is comparable to biomass burning smoke (Giannakaki et al., 2010; Amiridis et al., 2009). During this period also AOD is significantly increased, suggesting that similar to groundbased aerosol in the region (e.g. Vakkari et al., 2013) the seasonality of elevated aerosol layers is dominated by combustion sources. The mean free-tropospheric contribution to the AOD of aerosol layers is $46 \%$ which can reach up to $96 \%$. Mean Ångström exponent related to extinction was found to be 1.8 both for dry and biomass burning periods, indicating the same size of particles for both biomass burning and polluted aerosols.

Acknowledgements. This work has been partly supported by the European Commission 6th Framework programme under the EUCAARI project (contract no. 036833-2). Elina Giannakaki acknowledges the support of the Academy of Finland (project no. 270108). The authors acknowledge the staff of the North-West University for valuable assistance and routine maintenance of the lidar. We also acknowledge Eskom and Sasol for their logistical support for measurements at Elandsfontein.

Edited by: M. Tesche

\section{References}

Althausen, D., Engelmann, R., Baars, H., Heese, B., Ansmann, A. Müller, D., and Komppula, M.: Portable Raman Lidar Polly XT for Automated Profiling of Aerosol Backscatter, Extinction, and Depolarization, J. Atmos. Ocean. Technol., 26, 2366-2378, doi:10.1175/2009jtecha1304.1, 2009.

Amiridis, V., Balis, D. S., Giannakaki, E., Stohl, A., Kazadzis, S., Koukouli, M. E., and Zanis, P.: Optical characteristics of biomass burning aerosols over Southeastern Europe determined from UVRaman lidar measurements, Atmos. Chem. Phys., 9, 2431-2440, doi:10.5194/acp-9-2431-2009, 2009.

Anderson, T. L., Masonis, S. J., Covert, D. S., Ahlquist, N. C., Howell, S. G., Clarke, A. D., and McNaughton, C. S.: Variability o aerosol optical properties derived from in situ aircraft measurements during ACE-Asia, J. Geophys. Res., 108, 8647, doi:10.1029/2002JD003247, 2003.

Andreae, M. O., Rosenfeld, D., Artaxo, P., Costa, A. A., Frank, G. P., Longo, K. M., and Silva-Dias, M. A. F.: Smoking rain clouds over the Amazon, Science, 303, 1337-1342, doi:10.1126/science.1092779, 2004.

Ångström, A.: The parameters of atmospheric turbidity, Tellus, 16, 64-75, doi:10.1111/j.2153-3490.1964.tb00144.x, 1964.

Ansmann, A., Wandinger, U., Riebesell, M., Weitkamp, C., and Michaelis, W.: Independent measurement of extinction and backscatter profiles in cirrus clouds by using a combined Raman elastic-backscatter lidar, Appl. Optics, 31, 7113-7131, doi:10.1364/AO.31.007113,1992.

Ansmann, A., Wagner, F., Müller, D., Althausen, D., Herber, A., von Hoyningen-Huene, W., and Wandinger, U.: European pollution outbreaks during ACE 2: Optical particle properties inferred from multiwavelength lidar and star-Sun photometry, J. Geophys. Res., 107, AAC 8-1-AAC 8-14, doi:10.1029/2001jd001109, 2002.

Baars, H., Ansmann, A., Althausen, D., Engelmann, R., Heese, B., Müller, D., Artaxo, P., Paixao, M., Pauliquevis, T., and Souza, R.: Aerosol profiling with lidar in Amazon Basin during the wet and dry season, J. Geophys. Res., 117, D21201, doi:10.1029/2012JD018338, 2012.

Balis, D. S., Amiridis, V., Nickovic, S., Papayannis, A., and Zerefos, C.: Optical properties of Saharan dust layers as detected by a Raman lidar at Thessaloniki, Greece, Geophys. Res. Lett., 31, L13104, doi:10.1029/2004g1019881, 2004.

Bösenberg, J., Matthias, V., Amodeo, A., et al.: EARLINET: A European Aerosol Research Lidar Network to establish an Aerosol Climatology, final report, MPI Rep. 348, Max-Planck-Inst. für Meteorol., Hamburg, Germany, 6-31, 2003.

Brooks, I. M.: Finding boundary layer top: Application of a wavelet covariance transform to lidar backscatter profiles, J. Atmos. Ocean Tech., 20, 1092-1105, doi:10.1175/15200426(2003)020<1092:FBLTAO>2.0.CO;2, 2003.

Bryant R. G., Bigg, G. R., Mahowald, N. M., Eckardt F. D., and Ross, S. G. : Dust emission response to climate in southern Africa, J. Geophys. Res., 112, D09207, doi:10.1029/2005JD007025, 2007.

Campbell, J. R., Welton, E. J., Spinhirne, J. D., Ji, Q., Tsay, S. C., Piketh, S. J., Barenbrug, M., and Holben, B. N.: Micropulse lidar observations of tropospheric aerosols over northeastern South Africa during the ARREX and SAFARI 2000 dry season experi- 
ments, J. Geophys. Res., 108, 8497, doi:10.1029/2002jd002563, 2003.

Cosijn, C. and Tyson, P. D.: Stable discontinuities in the atmosphere over South Africa, S. Afr. J. Sci., 92, 381-386, 1996.

Draxler, R. R. and Hess, G. D.: Description of the HYSPLIT 4 modeling system, NOAA Tech Memo, ERL ARL-224, 24, NOAA, Silver Spring, Md., 1997.

Draxler, R. R. and Hess, G. D.: An overview of the HYSPLIT 4 modelling system for trajectories, dispersion and deposition, Aust. Meteorol. Mag., 47, 295-308, 1998.

Eck, T. F., Holben, B. N., Ward, D. E., Mukelabai, M. M., Dubovik, O., Smirnov, A., Schafer, J. S., Hsu, N. C., Piketh, S. J., Queface, A., Le Roux, J., Swap, R. J., and Slutsker, I.: Variability of biomass burning aerosol optical characteristics in southern Africa during the SAFARI 2000 dry season campaign and a comparison of single scattering albedo estimates from radiometric measurements, J. Geophys. Res., 108, 8477, doi:10.1029/2002jd002321, 2003.

Engelmann R., Althausen, D., Heese, B., Baars, H., and Komppula, M.: Recent upgrades of the multiwavelength polarization raman lidar polly $\mathrm{XT}$, 22nd International Laser and Radar Conference, Porto Heli, Greece, 25-29 June 2012, S1P-25, 2012.

Flamant, C., Pelon, J., Flamant, P. H., and Durand, P.: Lidar determination of the entrainment zone thickness at the top of the unstable marine atmospheric boundary layer, Bound.-Lay. Meteorol., 83, 247-284, doi:10.1023/a:1000258318944, 1997.

Formenti, P., Winkler, H., Fourie, P., Piketh, S., Makgopa, B., Helas, G., and Andreae, M. O.: Aerosol optical depth over a remote semi-arid region of South Africa from spectral measurements of the daytime solar extinction and the nighttime stellar extinction, Atmos. Res., 62, 11-32, doi:10.1016/s0169-8095(02)00021-2, 2002.

Formenti, P., Elbert, W., Maenhaut, W., Haywood, J., Osborne, S., and Andreae, M. O.: Inorganic and carbonaceous aerosols during the Southern African Regional Science Initiative (SAFARI 2000) experiment: Chemical characteristics, physical properties, and emission data for smoke from African biomass burning, J. Geophys. Res., 108, 8488, doi:10.1029/2002jd002408, 2003.

Freiman, M. T. and Piketh, S. J.: Air transport into and out of the industrial Highveld region of South Africa, J. Appl. Meteorol., 42, 994-1002, doi:10.1175/15200450(2003)042<0994:ATIAOO>2.0.CO;2, 2003.

Giannakaki, E., Balis, D. S., Amiridis, V., and Zerefos, C.: Optical properties of different aerosol types: seven years of combined Raman-elastic backscatter lidar measurements in Thessaloniki, Greece, Atmos. Meas. Tech., 3, 569-578, doi:10.5194/amt-3569-2010, 2010.

Giglio, L., Randerson, J. T., van der Werf, G. R., Kasibhatla, P. S., Collatz, G. J., Morton, D. C., and DeFries, R. S.: Assessing variability and long-term trends in burned area by merging multiple satellite fire products, Biogeosciences, 7, 1171-1186, doi:10.5194/bg-7-1171-2010, 2010.

Groß, S., Esselborn, M., Weinzierl, B., Wirth, M., Fix, A., and Petzold, A.: Aerosol classification by airborne high spectral resolution lidar observations, Atmos. Chem. Phys., 13, 2487-2505, doi:10.5194/acp-13-2487-2013, 2013.

Hänel, A., Baars, H., Althausen, D., Ansmann, A., Engelmann, R., and Sun, Y. J.: One-year aerosol profiling with EUCAARI Raman lidar at Shangdianzi GAW station: Beijing plume and seasonal variation, J. Geophys. Res., 117, D13201, doi:10.1029/2012JD017577, 2012.

Hantson S., Padilla, M., Corti, D., and Chuvieco, E.: Strengths and weaknesses of MODIS hotspots to characterize global fire occurrence, Remote Sens. Environ., 131, 152-159, doi:10.1016/j.rse.2012.12.004, 2013.

Hirsikko, A., O'Connor, E. J., Komppula, M., Korhonen, K., Pfüller, A., Giannakaki, E., Wood, C. R., Bauer-Pfundstein, M., Poikonen, A., Karppinen, T., Lonka, H., Kurri, M., Heinonen, J., Moisseev, D., Asmi, E., Aaltonen, V., Nordbo, A., Rodriguez, E., Lihavainen, H., Laaksonen, A., Lehtinen, K. E. J., Laurila, T., Petäjä, T., Kulmala, M., and Viisanen, Y.: Observing wind, aerosol particles, cloud and precipitation: Finland's new groundbased remote-sensing network, Atmos. Meas. Tech., 7, 13511375, doi:10.5194/amt-7-1351-2014, 2014.

Hsu, N. C., Herman, J. R., and Weaver, C.: Determination of radiative forcing of Saharan dust using combined TOMS and ERBE data, J. Geophys. Res., 105, 20649-20661, doi:10.1029/2000jd900150, 2000.

Ichoku, C., Remer, L. A., Kaufman, Y. J., Levy, R., Chu, D. A., Tanre, D., and Holben, B. N.: MODIS observation of aerosols and estimation of aerosol radiative forcing over southern Africa during SAFARI 2000, J. Geophys. Res., 108, 8499, doi:10.1029/2002jd002366, 2003.

IPCC: The Physical Science Basis, Contribution of Working Group I to the Fifth Assessment Report of the Intergovernmental Panel on Climate Change, edited by: Stocker, T. F., Qin, D., Plattner, G.-K, Tignor, M., Allen, S. K., Boschung, J., Nauels, A., Xia, Y., Bex, V., and Midgley, P. M., Cambridge University Press, Cambridge, United Kingdom and New York, NY, USA, 2013.

Ito, A., Ito, A., and Akimoto, H.: Seasonal and interannual variations in $\mathrm{CO}$ and $\mathrm{BC}$ emissions from open biomass burning in Southern Africa during 1998-2005, Global Biogeochem. Cy., 21, GB2011, doi:10.1029/2006GB002848, 2007.

Klett, J. D.: Stable analytical inversion solution for processing lidar returns, Appl. Optics, 20, 211-220, doi:10.1364/AO.20.000211, 1981.

Komppula, M., Mielonen, T., Arola, A., Korhonen, K., Lihavainen, H., Hyvärinen, A.-P., Baars, H., Engelmann, R., Althausen, D., Ansmann, A., Müller, D., Panwar, T. S., Hooda, R. K., Sharma, V. P., Kerminen, V.-M., Lehtinen, K. E. J., and Viisanen, Y.: Technical Note: One year of Raman-lidar measurements in Gual Pahari EUCAARI site close to New Delhi in India - Seasonal characteristics of the aerosol vertical structure, Atmos. Chem. Phys., 12, 4513-4524, doi:10.5194/acp-12-4513-2012, 2012.

Koren, I., Kaufman, Y. J., Remer, L. A., and Martins, J. V., Measurement of the effect of Amazon smoke on inhibition of cloud formation, Science, 303, 1342-1345, doi:10.1126/science.1089424, 2004.

Koren, I., Martins, J. V., Remer, L. A., and Afargan H.: Smoke invigoration versus inhibition of clouds over the Amazon, Science, 321, 946-949, doi:10.1126/science.1159185, 2008.

Korhonen, K., Giannakaki, E., Mielonen, T., Pfüller, A., Laakso, L., Vakkari, V., Baars, H., Engelmann, R., Beukes, J. P., Van Zyl, P. G., Ramandh, A., Ntsangwane, L., Josipovic, M., Tiitta, P., Fourie, G., Ngwana, I., Chiloane, K., and Komppula, M.: Atmospheric boundary layer top height in South Africa: measurements with lidar and radiosonde compared to three atmospheric models, 
Atmos. Chem. Phys., 14, 4263-4278, doi:10.5194/acp-14-42632014, 2014.

Kulmala, M., Asmi, A., Lappalainen, H. K., et al.: General overview: European Integrated project on Aerosol Cloud Climate and Air Quality interactions (EUCAARI) - integrating aerosol research from nano to global scales, Atmos. Chem. Phys., 11, 13061-13143, doi:10.5194/acp-11-13061-2011, 2011.

Laakso, L., Vakkari, V., Virkkula, A., Laakso, H., Backman, J., Kulmala, M., Beukes, J. P., van Zyl, P. G., Tiitta, P., Josipovic, M., Pienaar, J. J., Chiloane, K., Gilardoni, S., Vignati, E., Wiedensohler, A., Tuch, T., Birmili, W., Piketh, S., Collett, K., Fourie, G. D., Komppula, M., Lihavainen, H., de Leeuw, G., and Kerminen, V.-M.: South African EUCAARI measurements: seasonal variation of trace gases and aerosol optical properties, Atmos. Chem. Phys., 12, 1847-1864, doi:10.5194/acp-12-1847-2012, 2012.

Lourens, A. S. M., Butler, T. M., Beukes, J. P., van Zyl, P. G., Beirle, S., Wagner, T. K., Heue, K. P., Pienaar, J. J., Fourie, G. D., and Lawrence, M. G.: Re-evaluating the $\mathrm{NO}_{2}$ hotspot over the South African Highveld, S. Afr. J. Sci., 108, 54-59, doi:10.4102/sajs.v108i11/12.1146, 2012.

Marufu, L., Dentener, F., Lelieveld, J., Andreae, M. O., and Helas, G.: Photochemistry of the African troposphere: Influence of biomass-burning emissions, J. Geophys. Res., 105, 14513 14530, doi:10.1029/1999jd901055, 2000.

Mattis, I., Muller, D., Ansmann, A., Wandinger, U., Preissler, J., Seifert, P., and Tesche, M.: Ten years of multiwavelength Raman lidar observations of free-tropospheric aerosol layers over central Europe: Geometrical properties and annual cycle, J. Geophys. Res., 113, D20202, doi:10.1029/2007jd009636, 2008.

Mona, L., Amodeo, A., Pandolfi, M., and Pappalardo, G.: Saharan dust intrusions in the Mediterranean area: Three years of Raman lidar measurements, J. Geophys. Res., 111, D16203, doi:10.1029/2005jd006569, 2006.

Müller, D., Mattis, I., Wandinger, U., Ansmann, A., Althausen, D., and Stohl, A.: Raman lidar observations of aged Siberian and Canadian forest fire smoke in the free troposphere over Germany in 2003: Microphysical particle characterization, J. Geophys. Res., 110, D17201, doi:10.1029/2004jd005756, 2005.

Müller, D., Ansmann, A., Mattis, I., Tesche, M., Wandinger, U., Althausen, D., and Pisani, G.: Aerosol-type-dependent lidar ratios observed with Raman lidar, J. Geophys. Res.-Atmos., 112, D16202, doi:10.1029/2006jd008292, 2007.

Murayama, T., Masonis, S. J., Redemann, J., Aderson, T. L., Schmid, B., Living J. M, Russell, P. B., Huebert, B., Howell, S. G., McNaughton, C. S., Clarke, A., Abo, M., Shimizu, A., Sugimoto, N., Yabuki, M., Kuze, H., Fukagawa, S., Maxwell-Meier K., Weber, R. J., Orsini, D. A., Blomquist, B., Bandy, A., and Thornton, D.: An intercomparison of lidarderived aerosol optical properties with airborne measurements near Toko during ACE-Asia, J. Geophys. Res., 108, 8651, doi:10.1029/2002JD003259, 2003.

Murayama, T., Müller, D., Wada, K., Shimizu, A., Sekigushi, M., and Tsukamato, T.: Characterization of Asian dust and Siberian smoke with multi-wavelength Raman lidar over Tokyo, Japan in spring 2003, Geophys. Res. Lett., 31, L23103, doi:10.1029/2004GL021105, 2004.

Papayannis, A., Amiridis, V., Mona, L., Tsaknakis, G., Balis, D., Bosenberg, J., Chaikovski, A., De Tomasi, F., Grigorov, I., Mattis, I., Mitev, V., Muller, D., Nickovic, S., Perez, C., Pietruczuk,
A., Pisani, G., Ravetta, F., Rizi, V., Sicard, M., Trickl, T., Wiegner, M., Gerding, M., Mamouri, R. E., D'Amico, G., and Pappalardo, G.: Systematic lidar observations of Saharan dust over Europe in the frame of EARLINET (2000-2002), J. Geophys. Res., 113, D10204, doi:10.1029/2007jd009028, 2008.

Pappalardo, G., Amodeo, A., Apituley, A., Comeron, A., Freudenthaler, V., Linné, H., Ansmann, A., Bösenberg, J., D’ Amico, G., Mattis, I., Mona, L., Wandinger, U., Amiridis, V., AladosArboledas, L., Nicolae, D., and Wiegner, M.: EARLINET: towards an advanced sustainable European aerosol lidar network, Atmos. Meas. Tech., 7, 2389-2409, doi:10.5194/amt-7-23892014, 2014.

Piketh, S. J., Tyson, P. D., and Steffen, W.: Aeolian transport from southern Africa and iron fertilization of marine biota in the South Indian Ocean, S. Afr. J. Sci., 96, 244-246, 2000.

Piketh, S. J., Swap, R. J., Maenhaut, W., Annegarn, H. J., and Formenti, P.: Chemical evidence of long-range atmospheric transport over southern Africa, J. Geophys. Res., 107, 4817, doi:10.1029/2002jd002056, 2002.

Prospero, J. M., Ginoux, P., Torres, O., Nicholson, S. E., and Gill, T.: Environmental characterization of global sources of atmospheric soil dust identified with the Nimbus 7 Total Ozone Mapping Spectrometer (TOMS) absorbing aerosol product, Rev. Geophys, 40, 1002, doi:10.1029/2000RG000095, 2002.

Queface, A. J., Piketh, S. J., Eck, T. F., Tsay, S. C., and Mavume, A. F.: Climatology of aerosol optical properties in Southern Africa, Atmos. Environ., 45, 2910-2921, doi:10.1016/j.atmosenv.2011.01.056, 2011.

Ramanathan, V., Crutzen, P. J., Kiehl, J. T., and Rosenfeld, D.: Aerosols, climate, and the hydrological cycle, Science, 294 2119-2124, doi:10.1126/science.1064034, 2001.

Robles-Gonzalez, C. and de Leeuw, G., Aerosol properties over the SAFARI-2000 area retrieved from ATSR-2, J. Geophys. Res., 113, D05206, doi:10.1029/2007JD008636, 2008.

Rosenfeld, D., Lohmann, U., Raga, G. B., O’Dowd, C. D., Kulmala, M., Fuzzi, S., Reissell, A., and Andreae, M. O.: Flood or drought: How do aerosols affect precipitation, Science, 321, 1309-1313, doi:10.1126/science.1160606, 2008.

Ross, K. E., Piketh, S. J., Bruintjes, R. T., Burger, R. P., Swap, R. J., and Annegarn, H. J.: Spatial and seasonal variations in CCN distribution and the aerosol-CCN relationship over southern Africa, J. Geophys. Res., 108, 8481, doi:10.1029/2002JD002384, 2003.

Roy, D. P., Boschetti, L., Justice, C. O. and Ju, J.: The collection 5 MODIS burned area product - Global evaluation by comparison with the MODIS active fire product, Remote Sens. Environ., 112, 3960-3707, doi:10.1016/j.rse.2008.05.013, 2008.

Swap R. J., Annegarn, H. J., Suttles, J. T., King, M. D., Platnick, S., Privette, J. L., and Scholes, R. J.: Africa burning: A thematic analysis of the Southern African Regional Science Initiative (SAFARI 2000), J. Geophys. Res., 108, 8465, doi:10.1029/2003JD003747, 2003.

Tesfaye, M., Sivakumar, V., Botai, J., and Tsidu, G. M.: Aerosol climatology over South Africa based on 10 years of Multiangle Imaging Spectroradiometer (MISR) data, J. Geophys. Res., 116, D20216, doi:10.1029/2011jd016023, 2011.

Tiitta, P., Vakkari, V., Croteau, P., Beukes, J. P., van Zyl, P. G., Josipovic, M., Venter, A. D., Jaars, K., Pienaar, J. J., Ng, N L., Canagaratna, M. R., Jayne, J. T., Kerminen, V.-M., Kokkola, H., Kulmala, M., Laaksonen, A., Worsnop, D. R., and Laakso, 
L.: Chemical composition, main sources and temporal variability of PM1 aerosols in southern African grassland, Atmos. Chem. Phys., 14, 1909-1927, doi:10.5194/acp-14-1909-2014, 2014.

Tummon, F., Solmon, F., Liousse, C., and Tadross, M.: Simulation of the direct and semidirect aerosol effects on the southern Africa regional climate during the biomass burning season, J. Geophys. Res., 115, D19206, doi:10.1029/2009JD013738, 2010.

Tyson, P. D. and Preston-Whyte, R. A.: The Weather and Climate of Southern Africa, Oxford University Press, Cape Town, 2004.

Vakkari, V., Beukes, J. P., Laakso, H., Mabaso, D., Pienaar, J. J., Kulmala, M., and Laakso, L.: Long-term observations of aerosol size distributions in semi-clean and polluted savannah in South Africa, Atmos. Chem. Phys., 13, 1751-1770, doi:10.5194/acp13-1751-2013, 2013.

Vakkari, V., Kerminen, V.-M., Beukes, J. P., Tiitta, P., van Zyl, P. G., Josipovic, M., Venter, A. D., Jaars, K., Worsnop, D. R., Kulmala, M., and Laakso, L.: Rapid changes in biomass burning aerosols by atmospheric oxidation. Geophys. Res. Lett., 41, 2644-2651, doi:10.1002/2014GL059396, 2014.
Venter, A. D., Vakkari, V., Beukes, J. P., van Zyl, P. G., Laakso, H., Mabaso, D., Tiitta, P., Josipovic, M., Kulmala, M., Pienaar, J. J., and Laakso, L.: An air quality assessment in the industrialised western Bushveld Ignous Complex, South Africa, S. Afr. J. Sci., 108, 1059, doi:10.4102/sajs.v108i9/10.1059, 2012.

Wagner, F., Müller, D. and Ansmann, A.: Comparison of the radiative impact of aerosols derived from vertically resolved (lidar) and vertically integrated (Sun photometer) measurements: Example of an Indian aerosol plume, J. Geophys. Res., 106, 2286122870, doi:10.1029/2001JD000320, 2001.

Wandinger, U. and Ansmann, A.: Experimental determination of the lidar overlap profile with Raman lidar, Appl. Opt., 41, 511-514, doi:10.1364/AO.41.000511, 2002.

Winkler, H., Formenti, P., Esterhuyse, D. J., Swap, R. J., Helas, G., Annegarn, H. J., and Andreae, M. O.: Evidence for largescale transport of biomass burning aerosols from sunphotometry at a remote South African site, Atmos. Environ., 42, 5569-5578, doi:10.1016/j.atmosenv.2008.03.031, 2008. 